\title{
PHARMACOGNOSTICAL STANDARDISATION OF LAGENANDRA TOXICARIA DALZ
}

\section{P Annie Sulochana Selvakumari}

Botany, St. John's College, Palayamkottai, Tamil Nadu, 62002, India.

*Corresponding Author: anniessp@yahoo.co.in

\begin{abstract}
Lagenandra toxicaria Dalz. of Araceae is endemic to South India. It is a semi aquatic herb growing gregariously in semi evergreen forests. By tradition rhizomes are considered carminative, tonic, diuretic and used in bilious complaints. The rhizome extract is said to have insecticidal and antimicrobial properties. Effective utilization of any information requires its systematic evaluation. Pharmacognosy is an important link between pharmacology and medicinal chemistry. Pharmacognostical standards are prepared by systematic study of the drug through morphological and anatomical descriptions of plants, pharmacognostical standards such as structural standards, analytical standards, physical constants and phytochemical analyses. The results of the present investigation provide dependable diagnostic features of the vegetative organs of the plants for the identity of the drug in entire and in fragmentary conditions.
\end{abstract}

(Keywords: Lagenandra toxicaria Dalz., pharmacognosy, anatomical characters, physichochemical constants, phytochemical screening )

\section{INTRODUCTION}

There are about 12 species of Lagenandra, mainly in Sri Lanka [1], one species in North East India and four species in South India [2]. Lagenandra toxicaria Dalz. of Araceae is endemic to peninsular India [3]. It is a semi aquatic herb, found in marshes and along watercourses, often growing gregariously in semi evergreen forests at the altitude of $350-1200 \mathrm{~m}$. Flowering and fruiting is between November and April. By tradition the plant is used in the preparations of ointments for skin itch and the rhizome is used in renal and cardiac ailments [4]. Rhizomes are considered carminative, tonic, diuretic and used in bilious complaints. The juice of the fresh plant is applied to wounds for quick healing [5]. Traditionally the plant is said to have insecticidal properties [6]. Effective utilization of any information requires its systematic evaluation. Recently, the plant was subjected to scientific studies and the rhizome oil of L. toxicaria has been shown to have antibacterial activity against the three human pathogens, namely Staphylococcus aureus, Escherichia coli and Klebsiella pneumoniae [7] by agar disc diffusion technique [8]. The rhizome oil was found to be more or less equally effective with that of the standard antibiotic chloramphenicol in the in vitro condition. The rhizome oil of L. toxicaria as well as possesses insecticidal and germicidal properties [9]. The oil was evaluated for its insecticidal activity against the storage pest Tribolium castanaem Herbst., by filter paper impregnation method and the LC50 value was found to be $0.069 \%$ in 24 hours [10]. Low concentration $(0.5 \mu \mathrm{l} / \mathrm{ml})$ of the oil in water totally inhibited the germination of seeds (Cicer arietinum, Oryza sativa and Vigna radiata), in the evaluation of germicidal activity carried out by the method of Rao and Singh [11]. The methanol extract of L. toxicaria (Rhizome) was subjected to column chromatographic technique. The oil obtained, was subjected to GC-MS analysis and the chemical constituents present in the oil were identified as Methyl ester of 2-hydroxy benzoic acid, Diethyl phthalate, Oleic acid, Palmitic acid ethyl ester and Dioctyl phthalate. Diethyl phthalate was found to be the major constituent $(89.46 \%)$ [12]. There has been no report of the pharmacognostical studies of L.toxicaria to date. Hence an attempt has been made to identify this useful medicinal plant. This paper focuses on the pharmacognosy of medicinally valued Lagenandra toxicaria Dalz. Pharmacognosy is essential because the men of ayurvedic have mentioned just the name of the drugs. Deforestation leads to the extinction of many drugs. Identification of the drugs becomes difficult. Hence, morphological and anatomical descriptions of plants are needed.

\section{MATERIALS AND METHODS}

\section{Macroscopic studies}

Periodic collection of the plant was undertaken. In determining the identity, Hooker's [13] Flora of British India, Gamble's Flora of the Presidency of Madras [14], 
Nicolson's Araceae in Dassanayake's [15] Flora of Ceylon, Mohanan and Henry's [16] Flora of Thiruvananthapuram, Kerala and more recent revisionary and other critical works were consulted. All vouchers of the collection were incorporated at the Herbarium of St. John's college, Palayamkottai. Identification of the species was confirmed with authentic herbarium specimens. Mature and healthy plants were collected and morphological characters were studied. Plants were examined using a hand lens in the field and a dissection microscope in the laboratory and the characters were noted down. Photographs of the specimens taken are also provided for easy identification.

\section{Microscopic studies}

\section{Anatomy}

The fresh plant parts (leaf, petiole, underground stem and root) were collected, cleaned, cut into pieces and fixed in 70\% ethanol FAA (Formalin: Acetic acid: Alcohol, 5:5:90). The fixed materials were dehydrated in tertiary butyl alcohol series [17], cleared in xylol and embedded in paraffin wax (Melting point $58^{\circ}-60^{\circ} \mathrm{C}$ ). Sections of $10 \mu \mathrm{m}$ thickness were cut in a rotary microtome (Spencer model), stained with toluidine blue [18] and mounted by following the usual plant microtechnique [19]. The anatomical characters were determined using NIKON-Lab phot 2 - Photographic Trinocular Microscopic Unit, using normal light and polarized light. Measurement of cells was made with micrometer. The permanent slides are kept in the Department of Botany, St. John's College, Palayamkottai, Tamil Nadu.

\section{Stomatal index}

Stomatal index is the percentage, which the number of stomata forms the total number of epidermal cells, each stoma being counted as one cell [20]. Fully developed leaves were cut into pieces of one sq. $\mathrm{cm}$ and boiled in $5 \%$ potassium hydroxide solution for 10 minutes. After thorough washings in water, the lower epidermal peels were taken off, stained with $1 \%$ aqueous safranin solution, and mounted in $50 \%$ glycerol. The stomatal index for a species is constant and is calculated by using the equation,

$$
I=\frac{S \times 100}{E+S}
$$

Where,

$\mathrm{I}=$ Stomatal index

$\mathrm{S}=$ Number of stomata per unit area

$\mathrm{E}=$ Number of epidermal cells in the same unit area
Averages of 10 measurements counting were taken after random sampling.

\section{Starch grains and raphides}

Finely powdered rhizome of the plants were mounted on glycerine as a thin film with Lugol's iodine solution and the characters of the starch grains and raphides were studied under light microscope. The sizes of starch grains and raphides were measured using micrometer and recorded.

\section{Scanning Electron Microscopic study}

Finely powdered and sieved samples (rhizome) were mounted on specimen stubs using Scotch double adhesive tapes and coated with gold to a thickness of $100 \mathrm{~A}^{\circ}$ using Hitachi vacuum evaporator model HUS 5GB. Gold-coated plates were observed in a Hitachi Scanning Electron Microscope model S-450, operated at $15 \mathrm{KV}$ and photographed.

\section{Fluorescence analysis}

The powdered sample and the extract of the powder in various solvents such as petroleum ether $\left(40^{\circ}-60^{\circ} \mathrm{C}\right)$, benzene, chloroform, methanol and water were examined under ordinary light and ultra violet light $(365 \mathrm{~nm}$ and $255 \mathrm{~nm})$. The powder was also treated with various chemical reagents and the change in colour was recorded. The fluorescent characters were determined.

\section{Physicochemical characters}

The percentage of loss of weight on drying, total ash, acid-insoluble ash, water-soluble ash, sulphated ash and residue on ignition were obtained by employing standard methods of analysis as described in Pharmacopoeia of India [21].

\section{Phytochmistry}

\section{Preliminary phytochemical analysis}

$10 \mathrm{~g}$ of the powdered sample was successively extracted with $200 \mathrm{ml}$ of petroleum ether $\left(40^{\circ}-60^{\circ} \mathrm{C}\right)$, benzene, chloroform, and methanol in a soxhlet apparatus. The different extracts were tested for the steroids, sugars, reducing sugars, triterpenoids, alkaloids, phenolic compounds, flavonoids, catechins, saponins, tannins, anthroquinones and amino acids by qualitative analyses [22]. 


\section{Paper Chromatography}

The water extract of the dry powder was subjected to paper chromatographic studies using Whatmann No. 1 filter paper. Identification of amino acids by paper chromatography was also performed using standards [22].

\section{Detection of cyanogenic glycosides}

$10 \mathrm{~g}$ of the fresh rhizome was cut into pieces and placed in a conical flask with $1 \mathrm{~N} \mathrm{HCl}$. The cut pieces were soaked in diluted hydrochloric acid for a few hours. $\mathrm{HCN}$ formed. A drop of sodium hydroxide and ferrous sulphate solution was taken in a filter paper. HCN solution was added to the impregnated filter paper. Appearance of Prussian blue colour showed the presence of cyanogenic glycosides [23].

\section{Quantitative estimations}

Quantitative estimations of starch, sugars, lipids, amino acids, proteins, nitrogen, phenolic compounds, flavonoids, calcium, sodium, potassium and iron were carried out [24].

\section{RESULTS AND DISCUSSION}

\section{Morphological features}

Marsh herb, 70-80 $\mathrm{cm}$ high. Rhizome creeping to ascending, $\quad 2-3.5 \mathrm{~cm}$ wide. Leaves elliptic to oblong. $15-35 \times 6-12 \mathrm{~cm}$, acute at ends, margin undulate, cataphylls ca. $15 \mathrm{~cm}$ long, petiole ca. $25 \mathrm{~cm}$ long, sub-cylindric. Peduncles upto $15 \mathrm{~cm}$ long. Spathe ovate to lanceolate, $7-15 \mathrm{~cm}$ long, acuminate at apex, with 2 parts, a basal tube with fused margins and an apical blade, dark brown outside and dark purple / pale yellow inside. Spadix ca. $1.5 \mathrm{~cm}$ long. Flowers possess powerful odour. Staminate flower near the apex, stamens 2 - 3, sessile, perianth 0 . Pistillate flowers at base, numerous, spirally arranged, stigma sessile. Berry ovoid, seeds $3-6$.

Notes:

The taxanomic tangle in Lagenandra ovata and Lagenandra toxicaria has been resolved [25] and these two species are treated as distinct. In L. ovata leaves ovate to ovate-lanceolate, spathe is dark purple inside and outside, warted outside, swollen at base and twisted at apex. In L. toxicaria on the other hand leaves elliptic oblong, spathe is dark brown outside and dark purple / pale yellow inside, smooth outside, neither swollen at the base nor twisted at the apex.

\section{Anatomical features}

\section{Lamina}

Dorsiventral. Epidermis is single layered; cells are vertically elongated, not of uniform size. Cuticle is thick showing ribbing in complex pattern on both the surfaces. Stomata are on upper and lower epidermis and are cyclocytic. Mesophyll is well differentiated into palisade and spongy parenchyma. Palisade cells are embedded in one row and confined to adaxial surface. The second row is rather poorly developed. Spongy parenchyma is about ten layered, contains tannin cells, mucilage cells, vascular bundles and raphide sacs containing needles of calcium oxalate in bundles. Vascular bundles consist of tracheids and thin-walled parenchyma. Xylem is situated towards the adaxial and phloem towards the abaxial sides.

\section{Petiole}

Outline is circular in cross section. Epidermis is single layered with thick cuticle. Sclerenchymatous strands are discontinuous and sub-adjacent to epidermis. There is no distinction between the cortex and the central cylinder. Ground tissue is parenchymatous with air canals. The size of the air cavities is larger towards the centre. Vascular bundles are many, consisting of tracheary elements and parenchyma. Each vascular bundle is with one file of wide metaxylem elements and a phloem strand; some include extended protoxylem.

\section{Rhizome}

The epidermis remains intact. The outer cortex is parenchymatous with air cavities. Tannin cells and mucilage cells are present. Parenchymatous cells contain starch. Calcium oxalate in the form of raphides is found in clusters in raphide sacs. Inner cortex is also aerenchymatous, with scattered amphivasal vascular bundles. Each vascular bundle consists of a cylinder of tracheary elements surrounding a core of phloem. There is no sclerenchyma. Internal periderm is observed.

\section{Root}

Epidermis is single layered. Outer cortex is parenchymatous with air spaces. Middle cortex is lacunate with large air cavities. Inner cortex is parenchymatous. Endodermis is distinct. Xylem strands alternate with phloem units, especially along the periphery of the central cylinder. Xylem consists of vessels, tracheids and associated parenchyma. Tannin cells are present. Pith is parenchymatous. Needles of calcium oxalate are present. 


\section{Stomatal index}

Stomatal index is constant for any species and has been proved useful for distinguishing leaflets of Indian from those of Alexandrian Senna and leaves of Atropa belladonna from those of Atropa acuminata. Stomatal index in L. toxicaria is 4.8 .

\section{Starch grains and calcium oxalate crystals}

When examined by polarized light, using crossed nicols, starch granules appeared as luminous objects on a black background. When the nicols were rotated through a right angle, the field became bright while the granules were dark with a bright cross representing the position of the hilum.

The starch grains of L. toxicaria are simple and irregularly ovoid. Bundles of acicular raphides are present in sacs. The length of the calcium oxalate needles vary from $70-180 \mu$, often over $110 \mu$.

Notes:

When the powdered sample was observed under the light microscope, phenolic compounds in the form of yellow and pink patches were observed along with the remnant of the cells, starch grains, and calcium oxalate crystals; in the sample studied.

\section{Scanning Electron Microscopic study of starch grains}

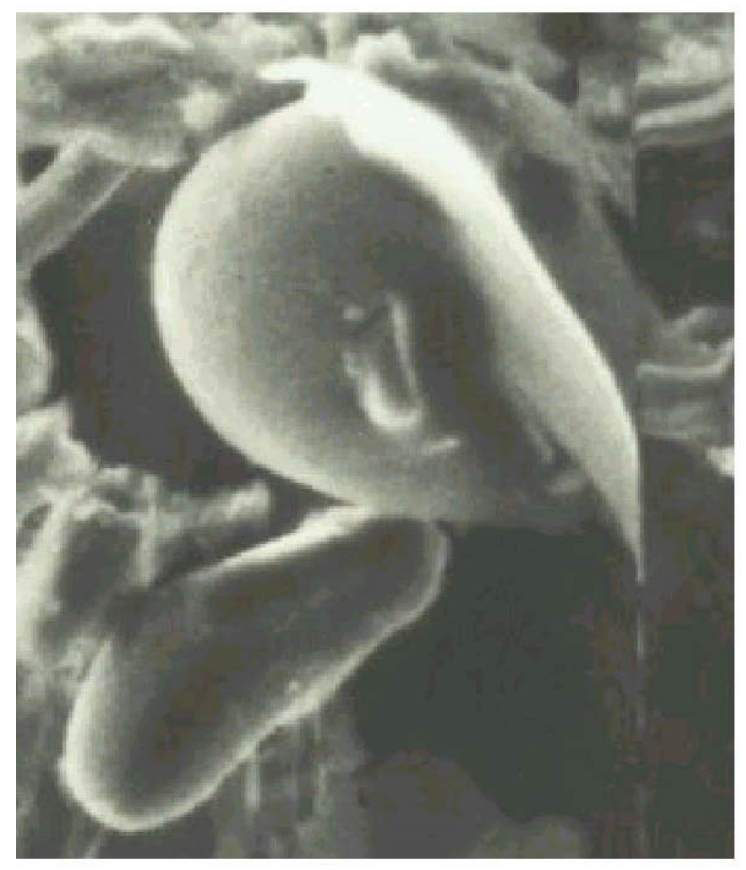

Starch grains (700 times magnified in the electronmicrograph) in the rhizome of L. toxicaria are irregularly ovoid, flattened, curved, sometimes globular, smooth and simple. Their length vary from $30-65 \mu$, mostly around $45-55 \mu$. Hilum is eccentric.

\section{DISCUSSION}

The gross morphology gives definite information about the drug. Morphological characters for the identification of the taxa have been described and photographs are displayed (Plate 1).

Microphotographs showing the anatomical characters of the plants are displayed (Plates 2 and 3). Druses are common. Cyclocytic stomata are present on adaxial and abaxial sides of the leaves. This has been quite regularly used for many years by pharmacognosists when identifying and maintaining acetable standard of purity for crude drugs [26]. The leaf epidermal cells have no undulation of side wall. Most undulations of the sidewalls of the epidermal cells appeared in leaves grown in shade [27].

The leaf of L. toxicaria, in its anatomy is distinct by having cuticular ribbing, epidermal cells of varied sizes, many layered mesophyll, embedded palisade tissue and presence of mucilage cells. Stomatal index in L. toxicaria is 4.8 . The stomatal index is less in semiaquatic plants. Variation in the epidermal structure has been extensively exploited for the purpose of taxonomy and phylogeny in vascular plants [28]. Cuticular thickenings are due to the cell walls of certain palisade cells, which orient themselves beneath the epidermal cell [29]. Large air cavities are observed in the petiole of L. toxicaria, showing aquatic character. Needles of calcium oxalate crystals are scattered.

The rhizome of L. toxicaria shows no cork development, vascular bundles are amphivasal and ground tissue is with air cavities. Besides, tannin cells are frequent, starch grains are simple and oval and calcium oxalate crystals are long. The polarized light was very much useful to detect the lignified elements, crystals and starch grains.

Vessels are restricted to metaxylem of the roots The roots show the primary structure with epidermis, aerenchymatous cortex and distinct endodermis enclosing the stele. The cortex is differentiated into three regions and the middle cortex with large air cavities. Histological study is valuable for the identification of the drugs.

The calcium oxalate needles of L. toxicaria are long. Bundles of acicular raphides are present in sacs. The 
length of the calcium oxalate needles vary from 70 $180 \mu$, often over $110 \mu$. The identity of many adulterants of drugs can be established or confirmed by an examination of calcium oxalate crystals [30].

Phenolic compounds in the form of pink and yellow patches have been observed in the dry powder of the rhizome. Presence of colouring matter also may be of assistance for the identification of the drugs and the deduction of adulterants.

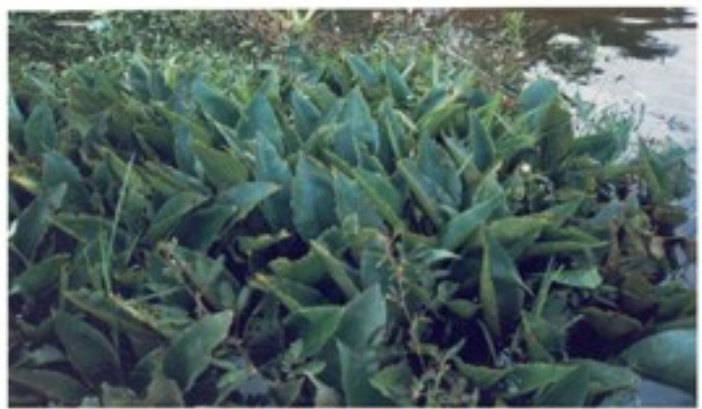

1.1 Lagenandra toxicaria in its natural habitat (Karayaar)

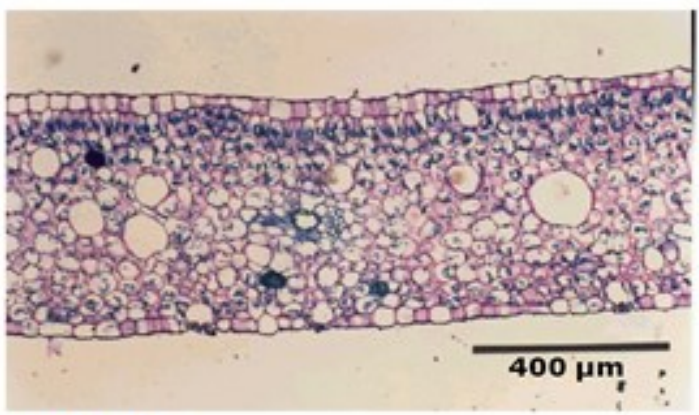

1.3 Leaf T.S

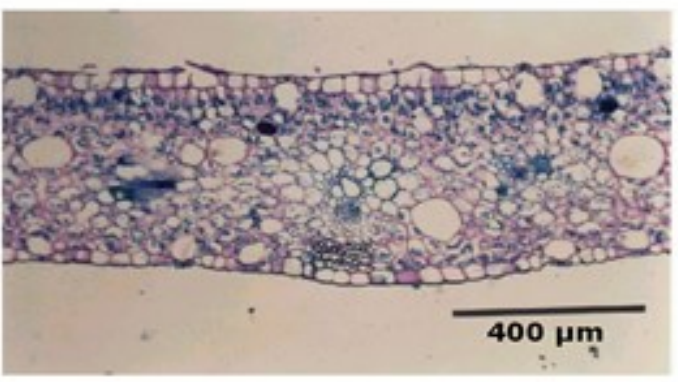

1.5 Lead mid rib- T.S
The shape of the starch granule, its size and position of its hilum vary with the species and therefore are important elements for microscopical identification [31]. The diameter of the starch granules assists in distinguishing varieties of Ipecacuanha and in distinguishing Cassia bark from Cinnamon and in detecting Senna stalk in powdered Senna leaf [27]. Hence, the Scanning Electron Microscopic studies on the starch grains of the species will be of great use in confirming the identity of the crude drugs.

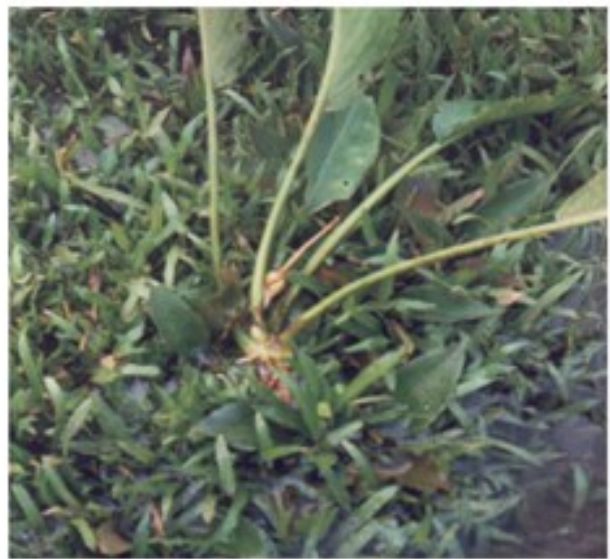

1.2 Lagenandra toxicaria with inflorescence

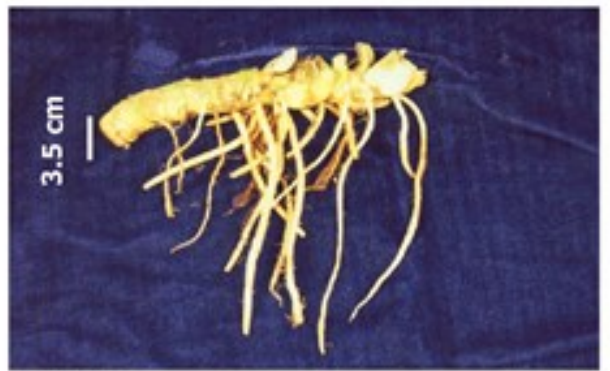

1.4 Rhizome

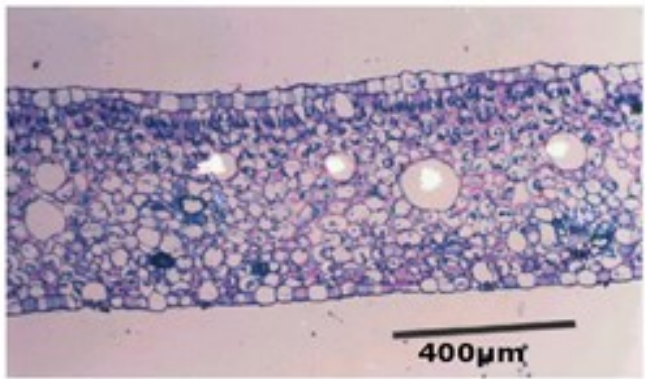

1.6. Leaf lamina- T.S (Polarised Light)

Plate 1. Lagenandra toxicaria Dalz 


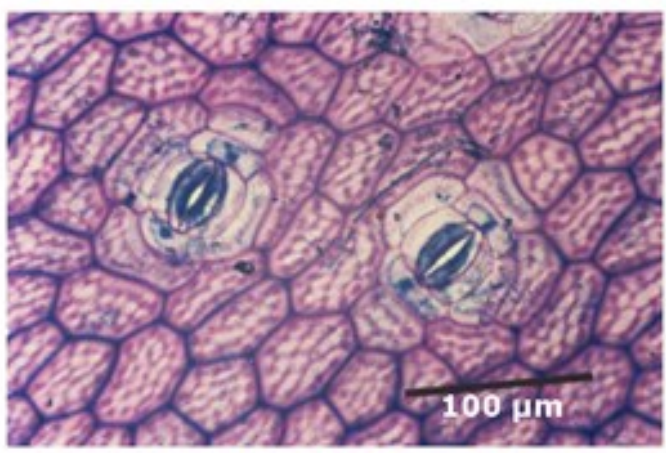

2.1 Leaf paradermal section - Cuticular thickening Cyclocytic

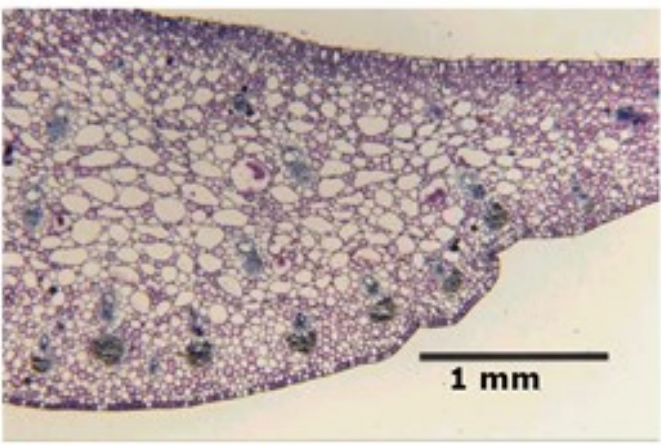

2.3 Leaf Sheath T.S

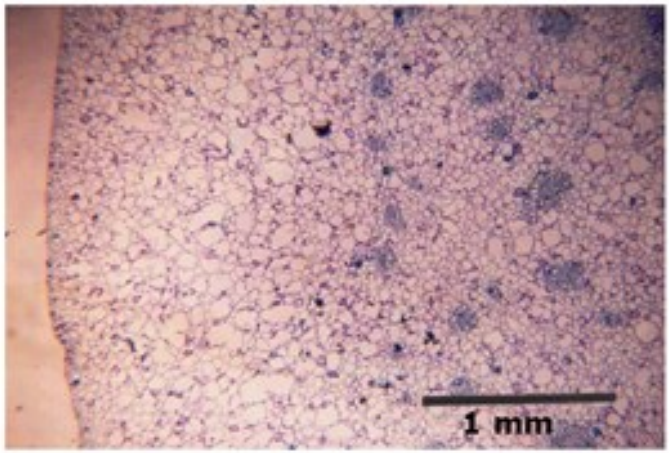

2.5 Corm T.S

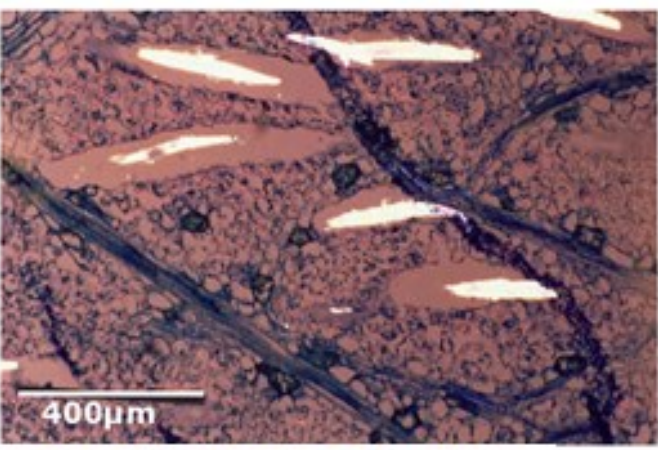

2.2 Leaf paradermal section - druses (Polarised Light)

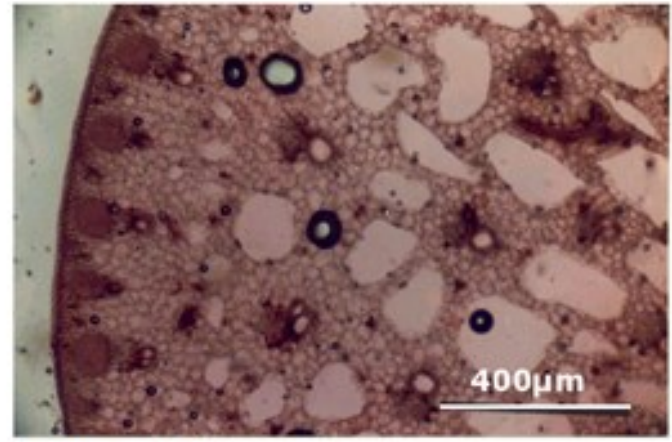

2.4 Petiole T.S.

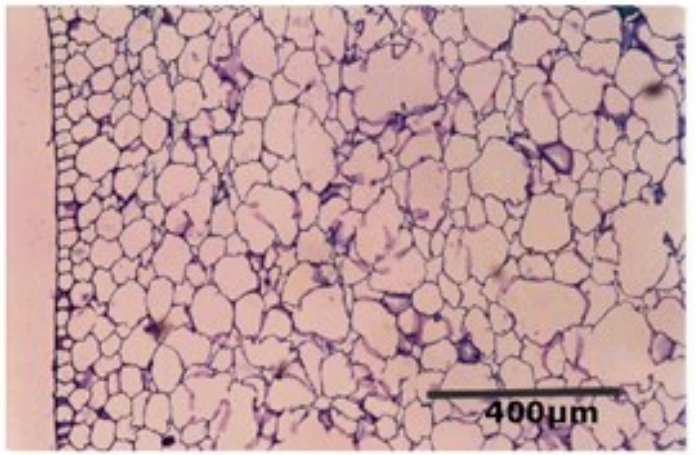

2.6 Corm T.S - Outer Sector

Plate 2. Lagenandra toxicaria 


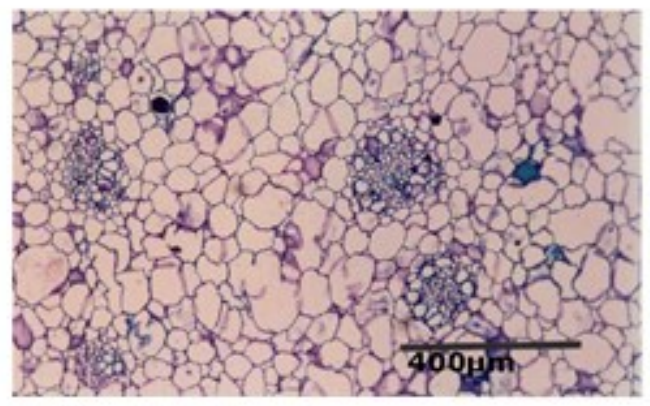

3.1 Corm T.S - Inner Sector

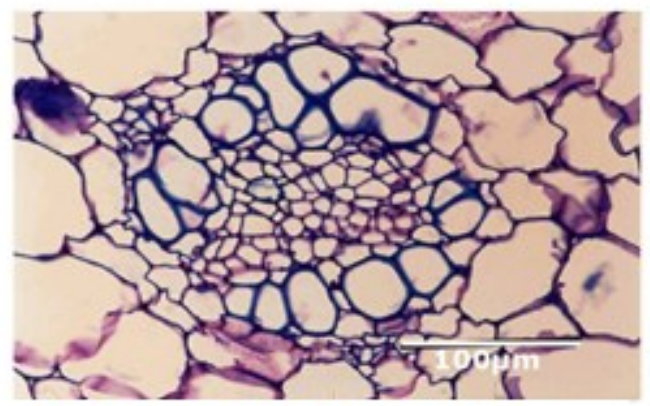

3.3 Corm T.S - single vascular bundle (amphivasal)

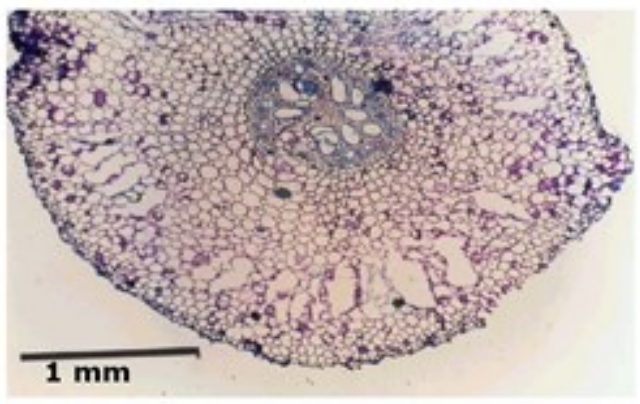

3.5 Root T.S

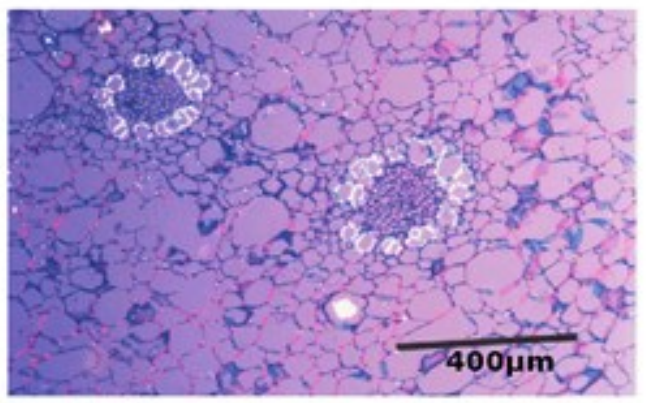

\subsection{Corm T.S - Inner Sector} (Polarised Light)

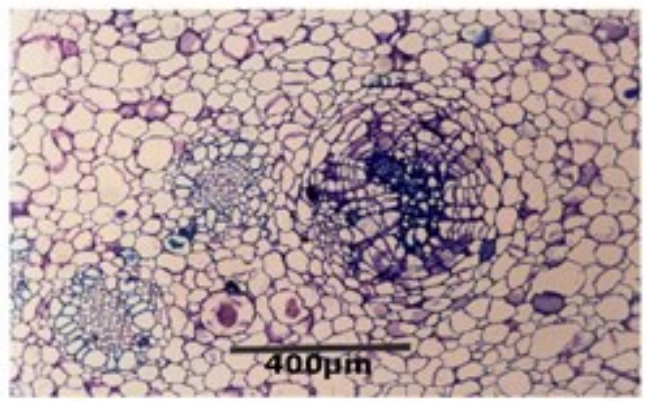

3.4 Corm T.S - vascular bundles and Periderm tube

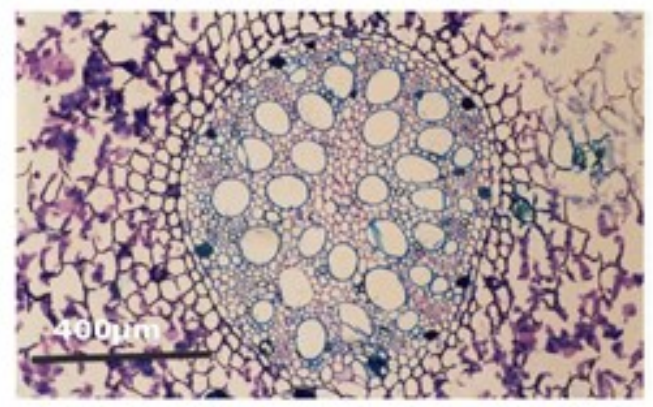

3.6 Root T.S - stelar portion

Plate 3 . Lagenandra toxicaria

The results of fluorescence analyses of the dry powder of the three taxa are presented in Table 1. Many alkaloids, in the solid-state show distinct colours, when placed under the UV lamp. The reaction of the various chemical compounds present in the dry powder of the plant drug with different acid and alkali shows the colour change and the fluorescence can be determined under UV light. Drugs such as Hydrastis, Calumba, Viburnum and wild Cherry bark show brilliant effect in ultraviolet light and these may be used to aid in identification and to detect certain adulterants, which do not exhibit a similar fluorescence [32]. 
Table 1. Fluorescent character of the powder of Lagenandra toxicaria (Rhizome)

\begin{tabular}{|c|c|c|c|c|}
\hline \multirow{2}{*}{ S.No. } & \multirow{2}{*}{ Particulars of treatment } & \multirow{2}{*}{$\begin{array}{c}\text { Under ordinary } \\
\text { light }\end{array}$} & \multicolumn{2}{|c|}{ Under UV light } \\
\hline & & & $365 \mathrm{~nm}$ & $255 \mathrm{~nm}$ \\
\hline 1. & Powder as such & Brown & Yellowish brown & Yellowish brown \\
\hline 2. & $\begin{array}{l}\text { Powder }+1 \mathrm{~N} \mathrm{NaOH} \\
\text { (ethanolic) }\end{array}$ & Dark brown & Brown & Yellowish brown \\
\hline 3. & $\begin{array}{l}\text { Powder }+1 \mathrm{~N} \mathrm{NaOH} \\
\text { (aqueous) }\end{array}$ & Dark brown & Dark brown & Brown \\
\hline 4. & Powder + $\mathrm{HCl}(1: 1)$ & Dark brown & Dark brown & Light brown \\
\hline 5. & Powder $+\mathrm{H}_{2} \mathrm{SO}_{4}(1: 1)$ & Brown & Yellowish brown & Pale yellow \\
\hline 6. & Powder $+\mathrm{HNO}_{3}(1: 1)$ & Reddish brown & Greenish brown & Olive green \\
\hline 7. & $\begin{array}{l}\text { Extracts } \\
\text { a) Petroleum ether } \\
\left(40^{\circ}-60^{\circ} \mathrm{C}\right)\end{array}$ & Pale yellow & Pale yellow & Orange \\
\hline & b) Benzene & Yellow & Greenish yellow & Orange \\
\hline & c) Chloroform & Brown & Greenish yellow & Orange \\
\hline & d) Methanol & Brown & Olive green & Greenish brown \\
\hline & e) Water & Brown & Olive green & Greenish brown \\
\hline
\end{tabular}

Table 2 shows the physicochemical characters of the drug. The physicochemical characters such as percentage of loss of weight on drying, total ash, acid- insoluble ash, water-soluble ash, sulphated-ash, residue on ignition of the sample was determined. These values are rarely constant for drugs, but may be within a range.

Table 2. Physicochemical Characters of the rhizome of Lagenandra toxicaria

\begin{tabular}{rlc}
\hline S.No. & \multicolumn{1}{c}{ Characters } & Percentage \\
\hline 1. & Loss of weight on drying & 81.86 \\
2. & Total ash & 12.83 \\
3. & Water- soluble ash & 3.28 \\
4. & Acid- insoluble ash & 3.11 \\
5. & Residue on ignition & 11.06 \\
6. & Sulphated ash & 13.13 \\
\hline
\end{tabular}

Loss of water in the sample is principally due to water; small amounts of other volatile materials also contribute to the weight loss. The moisture content of a drug should be minimized in order to prevent the decomposition of crude drugs due to either chemical change or microbial contamination.

The total ash usually consists mainly of carbonates, phosphates, silicates, and silica. The ash value is a criterion to judge the identity or purity of the crude drugs. In sulphated-ash determination, all oxides and carbonates are converted to sulphates. The sulphatedash content is more than the total ash content.

The water-soluble ash is used to detect the presence of material exhausted by water. Exhausted ginger and tea leaves are determined by water-soluble ash [30]. Acid insoluble-ash, which is a part of total ash, insoluble in diluted hydrochloric acid is also recommended as standard for certain drugs. Adhering dirt and sand may be determined by acid-insoluble ash content. Excessive earthy matter is likely to occur with roots and rhizomes. The percentages of solvent soluble extractives with reference to the powdered sample are given in Table 3. The extractive values of the methanol and aqueous extracts are generally high when compared to the other extractive values of the less polar solvents. Ether soluble extractive represents fat, volatile oil, resin, fixed oil or colouring matter present in the drug. Methanol is an ideal solvent for the extraction of various chemicals like tannins, flavonoids, amino acids and phenolic compounds. Water-soluble active constituents chiefly include tannins, sugars, plant acids, mucilage and glycosides. 
Malaysian Journal of Science 33(2): 163-175(2014)

Table 3. Solvent soluble extractive values of the rhizome Lagenandra toxicaria

\begin{tabular}{ccc}
\hline Name of the plant & Name of the solvent & $\begin{array}{c}\text { Percentage of } \\
\text { extractive values }\end{array}$ \\
\hline & Petroleum ether $\left(40^{\circ}-60^{\circ} \mathrm{C}\right)$ & 4.10 \\
Lagenandra toxicaria & Benzene & 6.02 \\
(Rhizome) & Chloroform & 15.34 \\
& Methanol & 19.90 \\
& Water & 25.46 \\
\hline
\end{tabular}

The determination of different solvent soluble extractive values is used as means of evaluating drugs, the constituents of which are not estimated by other means. Nevertheless, as suitable assays become available the extractive tests are no longer required as pharmacopoeial standards [33].

Table 4 gives the results of the preliminary phytochemical screening. Table 5, show the thin layer chromatographic studies of the various extracts while Table 6 show the paper chromatographic studies of the water extract. Table 7 gives the elemental analysis, Table 8 shows the paper chromatographic analysis of amino acids and lastly Table 9 shows the quantitative estimation of total sugars, starch, amino acids, proteins, lipids, total phenolic compounds and flavonoids in the underground stems of L. toxicaria.

Table 4. Preliminary phytochemical screening of Lagenandra toxicaria (Rhizome)

\begin{tabular}{llcccc}
\hline S.No. & \multicolumn{1}{c}{ Phytochemicals } & $\begin{array}{c}\text { Petroleum ether } \\
\left(40^{\circ}-60^{\circ} \mathrm{C}\right) \\
\text { extract }\end{array}$ & $\begin{array}{c}\text { Benzene } \\
\text { extract }\end{array}$ & $\begin{array}{c}\text { Chloroform } \\
\text { extract }\end{array}$ & $\begin{array}{c}\text { Methanol } \\
\text { extract }\end{array}$ \\
\hline 1. & Steroids & + & + & + & + \\
2. & Triterpenoids & - & - & + & + \\
3. & Reducing Sugars & + & + & + & + \\
4. & Sugars & + & - & - & + \\
5. & Alkaloids & - & - & - & + \\
6. & Phenolic compounds & - & - & - & + \\
7. & Flavonoids & - & - & - & + \\
8. & Catechins & - & - & - & + \\
9. & Saponins & - & - & - & + \\
10. & Tannins & - & - & + & + \\
11. & Anthroquinones & - & & + & + \\
12. & Amino acids & - & & & + \\
\hline
\end{tabular}

Notes : - Absent and + Present 
Table 5. Thin layer chromatographic studies of the various extracts of the dry powder of the rhizome.

\begin{tabular}{|c|c|c|c|}
\hline $\begin{array}{l}\text { Name of } \\
\text { the extract }\end{array}$ & Solvent system used & $\begin{array}{c}\text { Rf values of spots obtained by } \\
\text { viewing under UV light ( } 365 \mathrm{~nm})\end{array}$ & $\begin{array}{l}\text { Rf values of spots obtained by } \\
\text { keeping plates in an Iodine } \\
\text { chamber }\end{array}$ \\
\hline $\begin{array}{l}\text { Petroleum } \\
\text { ether } \\
\left(40^{\circ}-60^{\circ} \mathrm{C}\right)\end{array}$ & $\begin{array}{c}\text { Petroleum ether } \\
\left(40^{\circ}-60^{\circ} \mathrm{C}\right): \\
\text { Benzene } \\
(5: 1)\end{array}$ & $\begin{array}{c}\text { Brown } \\
0.07\end{array}$ & $0.07^{\ominus}$ \\
\hline Benzene & $\begin{array}{c}\text { Benzene: Chloroform } \\
(4: 1)\end{array}$ & $\begin{array}{l}\text { Orange } \\
0.42\end{array}$ & - \\
\hline Chloroform & $\begin{array}{l}\text { Chloroform: Methanol } \\
\qquad(9: 1)\end{array}$ & $\begin{array}{l}\text { Orange } \\
0.93\end{array}$ & $0.20^{\theta}$ \\
\hline \multirow[t]{2}{*}{ Methanol } & $\begin{array}{l}\text { Chloroform: Methanol } \\
\qquad(6: 1)\end{array}$ & $\begin{array}{c}\text { Brown } \\
0.16\end{array}$ & $\begin{array}{l}0.09^{\circ} \\
0.16^{\circ}\end{array}$ \\
\hline & & $\begin{array}{l}\text { Orange } \\
0.93\end{array}$ & $\begin{array}{l}0.19^{\circ} \\
0.38^{\circ}\end{array}$ \\
\hline
\end{tabular}

Notes: $\bullet$ Intense , $\theta$ Moderately intense and $\circ$ Faint

Table 6. Paper chromatographic studies of the water extract of the dry powder of the rhizome.

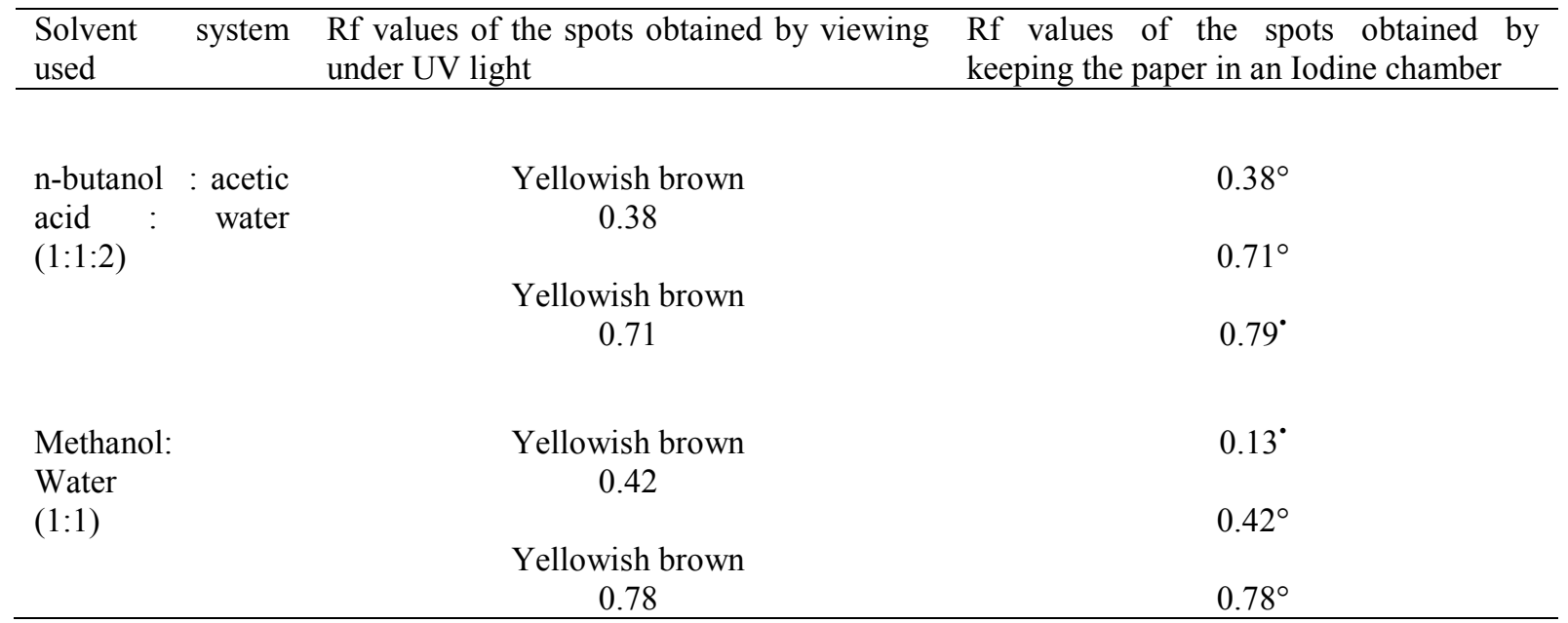

Notes: $\bullet$ Intense and $\circ$ Faint

Table 7. Elemental analysis of the rhizome of Lagenandra toxicaria

\begin{tabular}{lcccc}
\hline Name of the plant & $\begin{array}{c}\text { Calcium } \\
\mathrm{mg} / \mathrm{gdw}\end{array}$ & $\begin{array}{c}\text { Sodium } \\
\mathrm{mg} / \mathrm{gdw}\end{array}$ & $\begin{array}{c}\text { Potassium } \\
\mathrm{mg} / \mathrm{gdw}\end{array}$ & $\begin{array}{c}\text { Iron } \\
\mathrm{mg} / \mathrm{gdw}\end{array}$ \\
\hline $\begin{array}{l}\text { Lagenandra } \\
\text { toxicaria } \\
\text { (Rhizome) }\end{array}$ & 4.38 & 0.004 & 0.91 & 0.056 \\
\hline
\end{tabular}


Table 8. Paper chromatographic analysis of amino acids of the rhizome of Lagenandra toxicaria

\begin{tabular}{cccc}
\hline S.No. & Aminoacids & Rf value & Lagenandra toxicaria (Rhizome) \\
\hline 1. & Arginine & 0.21 & + \\
2. & DL-asparticacid & 0.25 & + \\
3. & DL-calamine & 0.38 & + \\
4. & DL-serine & 0.28 & - \\
5. & DL-Threonine & 0.37 & - \\
6. & DL-Tryptophan & 0.63 & + \\
7. & DL-valine & 0.54 & - \\
8. & Glycine & 0.30 & + \\
9. & Histidine & 0.20 & - \\
10. & L-cystine & 0.12 & + \\
11. & L-glutamicacid & 0.34 & + \\
12. & L-Leucine & 0.58 & + \\
13. & L-Proline & 0.41 & + \\
14. & L-Tyrosine & 0.56 & - \\
15. & Lysine & 0.15 & + \\
\hline Notes $:$ & - Absent, Present, Solvent & system - n-butanol: acetic acid: water $(4: 1: 5)$
\end{tabular}

Rf values obtained by thin layer chromatography patterns are useful to establish their identity and purity of the herbs. Stahl has discussed in detail, the importance of Thin-Layer Chromatography as a legally binding method for characterization of drugs [34]. Colchicine was not found in this species. Cyanogenesis, the ability to produce hydrocyanic acid ( $\mathrm{HCN})$ is common among Araceae. HCN does not occur free in higher plants but is released from cyanogenic precursors as the result of enzymatic action. In the present investigation also, the rhizome of L.toxicaria was found to possess cyanogenic glycosides.

Usually in the underground stems, the amount of starch is higher than the amount of sugar, because starch is the reserve food material in the rhizomes of the plants. Phenolic compounds are important constituents of some medicinal plants. In food industry, they are utilized as colouring agents, flavourings, aromatizers and antioxidants. Phenolic classes of pharmaceutical interest are tannins, coumarins, anthroquinones, napthoquinones, flavones and related flavonoid glycosides, anthocyanidins, lignans and other simple phenolic compounds. In plants, phenolic compounds play an important role in disease resistance. Phenols are also involved in the protection of herbs from browsing animals. Flavonoids are generally present in high amount in the plants growing in high altitude, because they absorb UV radiation. Flavonoids include the colouring agents of plants. Flavonoids are essentially used to treat capillary and venous disorders, alone or in combination with other drugs, they are the common ingredients of vascular protective agents and venous tonic [28]. The high calcium content is probably due to the presence of calcium oxalate crystals in the rhizome and free calcium. Inorganic elements play an important role in various physiological processes. There are evidences for using plants as indicators for mineralization.

It should be remembered, however, biosynthesis of secondary metabolites although genetically controlled, is affected by environmental influences. The soil, the season and the gathering time are some of the important variable factors with plants and it can hardly be expected that the amount of constituents would be constant under all conditions. These results could be used as a diagnostic tool for the identification of the species. The amino acid profile is a consistent character because they are genetical.

\section{CONCLUSION}

Pharacognostical study on Lagenandra toxicaria is reported for the first time. The macroscopical or morphological description of the taxa helps in identification of the plant. Microscopical study in entire and powdered form of the drug is one of the aspects of histological evaluation. The size, shape and structure of the starch granules and length of calcium oxalate crystals from any particular plants only vary within definite limits, so that it is possible to distinguish the starches derived from different species. Hence, the study of starch grains and calcium oxalate crystals is useful in confirming the identity and purity of the drug. The physicochemical constants, extractive values, fluorescence analysis and phytochemical analyses of the 
dry powder of the rhizome was determined by employing standard methods of analysis as described in Pharmacopoeia of India. Based on the pharacognostical parameters studied, it is possible to fit standard for the drugs. Thus, the results of the present investigation provide dependable diagnostic features of the vegetative organs of the plant for the identity of the drug in entire and in fragmentary.

\section{REFERENCE}

1. Nicolson D.H. (1987). Araceae In: Dassanayake A Revised Hand Book to the Flora of Ceylon, Vol. VI New Delhi, pp. 64-85.

2. Karthikeyan S., Jain S. K., Nayar M. P and Sanjappa M. (1989). Florae Indicae Enumeratio-Monocotyledonae, BSI, Calcutta pp. 7-16.

3. Nayar M. P. (1996). Hot Spots of Endemic Plants of India, Nepal and Bhutan, TBGRI, Trivandrum p. 217.

4. Chopra R. N., Chopra I. C., Honda K.L.and Kapur L.D. (1994). Indigenous Drugs of India, Second Edition, B. K. Dher of Academic Publishers, Calcutta, p.580.

5. Sivarajan V. V. and Indira Balachandran (1994). Ayurvedic Drugs and their plant sources, Oxford \& IBH Publishing Co., New Delhi pp. 162-163.

6. Kirtikar K. R. and Basu B. D. (1918). Indian Medicinal Plants, Vol. IV, 2602. ICS, Allahabad.

7. Annie Sulochana Selvakumari P. and John De Britto A. (2004). Lagenandra toxicaria - A potential medicinal herb for its antimicrobial activity, Proceedings of the National Conference on the frontiers of Research and Development in Medicinal Plants, St. Xavier's College, Palayamkottai, pp. 40-43.

8. Bauer A. W., Kirby R., Sherris J. C. Turk M. (1966). Antibiotic susceptibility testing by a standardised disc method. Am. J. Clin. Pathol. 45 493-496.

9. Annie Sulochana Selvakumari P. (2004). Pharmacognostical and Phytochemical Studies on some Medicinal Plants, Ph.D. thesis, Manonmaniam Sundaranar University, Tirunelveli, Tamil Nadu.
10. Annie Sulochana Selvakumari P. (2010). Insecticidal activity of Lgenandra toxicaria Dalz against Tribolium castaneum. Herbst. Indian Journal of Ecology, Lgenandra toxicaria Dalz 37(2) 224-225.

11. Annie Sulochana Selvakumari P. and John De Britto A. a (2008). GC-MS analysis of the Rhizome Oil of Lgenandra toxicaria Dalz., Malaysian Journal of Science 27 (1) 89-99.

12. Hooker J. D. (1894). Flora of British India,Vol. VI, L. Reeve \& Co., London pp. 495-510.

13. Fischer C. E. C. (1928). In: Gamble's Flora of Presidency of Madras, Adllard \& Son. Ltd., London, Vol. 3 1571- 1592.

14. Nicolson D.H. (1987). Araceae In: Dassanayake A Revised Hand Book to the Flora of Ceylon, Vol. VI New Delhi, pp. 64-85.

15. Mohanan M. and Henry A. N. (1994). Flora of Thiruvananthapuram, BSI, Kerala.

16. Sass J. E. (1940). Elements of botanical microtecnique, McGraw-Hill, Inc., New York.

17. O' Brien T. P., Fedar N. and Mc Cull M. E. (1964). Polychromatic staining of plantcell wallsby toluidine blue, O. Protoplasma 59 364-373.

18. Johansen Donald Alexander (1940).Plant Microtecnique, McGraw-Hill, Inc., New York pp. 126-154.

19. Salisbury E. J. (1927).In Wallis T. E. Pharmacognosy, Fifth Edition, CBS Publishers, New Delhi p. 113.

20. Anonymous, (1966). Pharmacopoeia of India, Second Edition, Govt. of India, Manager of Publications, New Delhi pp. 947-948.

21. Sadasivam S. and Manickam A., 1996. Biochemical methods for Agricultural Sciences, Wiley Eastern Ltd., New Delhi.

22. Sim S.K., (1988). Medicinal Plants Glycosides, University of Toronto Publication pp. 123-135.

23. A.O.A.C., (2001). Official Methods of Analysis, Association of Official Analytical Chemists, Washington D.C.

24. Annie Sulochana Selvakumari P. (2004). Pharmacognostical and Phytochemical Studies on some Medicinal Plants, Ph.D. thesis, 
Manonmaniam Sundaranar University, Tirunelveli, Tamil Nadu.

25. Tomlinson P. B. (1969). Anatomy of Monocotyledons Vol. IV, Oxford, Brittan p. 392.

26. Watson (1942). In: Observations on the epidermal structure and stomatal apparatus of some members of Araceae, Rhodora 62 pp.251-258.

27. Ghouse A. K. M. and Mohd Yunus (1972). Research trends in Plant Anatomy, McGraw-Hill, Inc., New Delhi.

28. Edgar Webber E. (1960). Observations on the epidermal structure and stomatal apparatus of some members of Araceae, Rhodora( 62) 251258.
29. Wallis T. E. (1997). Pharmacognosy, Fifth Edition, CBS Publishers, New Delhi pp. 555-560.

30. Jean Bruneton (1999). Pharmacognosy, Second Edition, Lavoisier Publishers, Inc. USA pp. 310$325 \& 175-182$.

31. Kokate C. K., Purohit A. P. and Gokhale S. B. (1997). Pharmacognosy, Nirali Prakashan, Pune pp. 105-137.

32. Evans W. C. (1996). Trease and Evans Pharmacognosy, Fourteenth Edition, Harcourt Brace Company, Asia pp. 191-218.

33. Stahl Egon, (1969). Thin- Layer Chromatography, Springer-Verlag, Berlin pp. 720-724. 